OPEN ACCESS

Edited by:

Victor Owusu,

Kwame Nkrumah University of

Science and Technology, Ghana

Reviewed by:

Kristal Jones,

University of Maryland, College Park,

United States

Godwin Horlu,

Tafila Technical University, Jordan

Robert Aidoo,

Kwame Nkrumah University of

Science and Technology, Ghana

${ }^{*}$ Correspondence: Assefa B. Amelework assefaa@arc.agric.za

Specialty section This article was submitted to Climate-Smart Food Systems, a section of the journal

Frontiers in Sustainable Food Systems

Received: 15 October 2020 Accepted: 17 March 2021

Published: 15 April 2021

Citation:

Amelework AB, Bairu MW, Maema O,

Venter SL and Laing M (2021) Adoption and Promotion of Resilient Crops for Climate Risk Mitigation and Import Substitution: A Case Analysis

of Cassava for South African

Agriculture.

Front. Sustain. Food Syst. 5:617783.

doi: 10.3389/fsufs. 2021.617783

\section{Adoption and Promotion of Resilient Crops for Climate Risk Mitigation and Import Substitution: A Case Analysis of Cassava for South African Agriculture}

\author{
Assefa B. Amelework ${ }^{1 *}$, Michael W. Bairu ${ }^{1}$, Obakeng Maema ${ }^{2}$, Sonja L. Venter ${ }^{1}$ and \\ Mark Laing ${ }^{3}$ \\ ${ }^{1}$ Agricultural Research Council, Vegetable and Ornamental Plants, Pretoria, South Africa, ${ }^{2}$ Technology Innovation Agency, \\ Pretoria, South Africa, ${ }^{3}$ African Centre for Crop Improvement, University of KwaZulu-Natal, Durban, South Africa
}

Cassava is an important starchy root crop grown globally in tropical and subtropical regions. The ability of cassava to withstand difficult growing conditions and long-term storability underground makes it a resilient crop, contributing to food security. Historically, small-scale farmers have grown cassava as a minor crop in the far north-eastern part of the country. However, there is an initiative to scale up cassava production, with two discrete areas of interest: large-scale production for industrial starch, and expanding its footprint as a food security crop for small-scale farmers, especially in the context of climate change. In this scoping study, production, processing and marketing data for cassava were accessed from the FAO and US Commercial trade databases. Other domestic market and demand analysis case studies were also explored. There is no cassava data available for South Africa. The study indicated that South Africa imports more than 66,000 tons of starch annually, of which $33 \%$ is cassava starch, showing the availability of a local market. The potential of cassava for the South African economy is discussed. Significant industrial opportunities exist for the production and use of cassava in South Africa. However, the realization of these opportunities will depend on the reliable supply of good quality cassava roots. However, the lack of a well-established cassava research program, and a lack of an existing value chain for the industrial scale cassava production and processing are barriers to the development of cassava industry in South Africa. As the initial step to the development of a successful cassava industry, high potential germplasm is imported, characterized and bred for local conditions to ensure the sustainable primary production of cassava. Subsequently, industrial value chains will need to be developed as the optimization of the breeding and agronomy of the crop are completed, and yield potentials are quantified in the different regions of the country.

Keywords: cassava breeding, climate change, import substitute, industrial application, value chain 


\section{INTRODUCTION}

Southern African Development Community (SADC) has recognized cassava as one of the potential industrial crops for SADC farmers (SADC Trade information Service). Cassava plays a key role in rural livelihoods in Africa especially in the tropics where the environment is both hot and dry. However, cassava is not among the traditional commodity crop in South Africa. South Africa's interest in cassava cultivation is mainly on high quality industrial starch production. Conversely, cassava is a versatile crop that offers immense opportunity as a food, feed, and industrial crop. In South Africa, the most suitable areas for cassava production are northern KwaZulu-Natal, the eastern parts of Limpopo and Mpumalanga. These areas all together have two million hectares of arable land, which is below $800 \mathrm{~m}$ elevation and an annual rainfall of $500 \mathrm{~mm}$ that is suitable for cassava production. However, currently smallholders in the far north-eastern region in South Africa have grown cassava as a minor crop.

The National Industrial Policy facilitates crop diversification beyond the country's current reliance on traditional crop commodities to promote non-traditional commodities that compete in export markets and reduce imports. This opens windows to promote cassava production in South Africa. Moreover, water scarcity presents difficulty in cropping maize, wheat and potato. Cassava has the ability to grow in a wider range of climatic conditions and soil types than other tropical staple crops. Relative to grain crops, cassava is more tolerant of low soil fertility and is more resistant to drought. Hence, cassava can provide South Africa with options for adaptation, whilst other major staples crops like maize and wheat face challenges. In addition, cassava has the potential to produce and store more carbohydrate than any other major grain or root crops (ElSharkawy and De Tafur, 2010). It can provides an option for the development of a novel industrial crop, with more than 300 industrial products including the manufacture of tire, adhesives, ethanol, pharmaceuticals, livestock feeds, biofuels, cold meats, and alcohol.

Characteristics such as low input requirements, tolerance to drought, the ability to grow in marginal soils and long-term storability of the roots in the ground make cassava a resilient crop for food and nutritional security (Jarvis et al., 2012). Cassava roots can be stored underground for as long as 24 months after maturity, and these can be harvested at any time of the year when a household needs food (Sanchez et al., 2013). Farmers can plant and harvest cassava without significant inputs, using marginal lands where other crops cannot be produced. Cassava typically yields $8-10$ tons ha- 1 of fresh storage roots with zero inputs. Consequently, cassava is widely produced in tropical regions by small-scale resource-limited farmers, who cannot afford to buy agro-chemicals or install irrigation systems (Costa and Delgado, 2019). Cassava provides an opportunity to improve smallholder farmers' income and food security by opening up marginal lands for cultivation.

Despite cassava's importance as a food security crop in Africa, and its industrial potential, relatively little research and development has been invested in cassava in southern Africa, compared to other root crops such as potato and sweet potato. There was a commercial starch processing plant that ran for several years in Mpumalanga but it has ceased to operate due to lack of raw material supply. Because, cassava production is dominated by disease-prone varieties with long maturation periods and low yield potential. Designing of a well-coordinated and well-structured cassava breeding program in the country is essential to create improved cassava cultivars with enhanced tuber yields and starch content as the basis for a cassava industry in South Africa. The increase in yield will lead to an increase in raw material supply to the industrial sector, which, in turn, will lead to an increase in income for the resource-poor farmers. In this desktop study, the importance of cassava as food, feed, and industrial crop has been reviewed. The study deals with the potential of cassava in the South African starch industry, the significance of crafting a sustainable R\&D strategy to support the industry, the development of the full value chain, and the importance of a national cassava breeding program. It is envisaged that this document will serve as a guide to develop the right technologies and appropriate approaches for integrating cassava into the farming system and to deliver economic benefits to both commercial and smallholder farmers.

\section{CASSAVA PRODUCTION IN THE WORLD}

The total worldwide cassava production in 1961 was 78.5 million tons grown on 9.6 million hectares, of which Africa contributed about 44\% (FAOSTAT, 2019). By 2017, world cassava production had increased to 322 million tons grown on 26 million ha of land (FAOSTAT, 2019). Although Africa accounts for more than $58 \%$ of cassava production and more than $75 \%$ of land area cultivated for cassava, the average fresh root yield of cassava is $8.9 \mathrm{t} \mathrm{ha}^{-1}$, which is far lower than the world average $(11.9 \mathrm{t}$ $\mathrm{ha}^{-1}$ ) and the yield observed in Asia $\left(13.3 \mathrm{t} \mathrm{ha}^{-1}\right.$ ) (FAOSTAT, 2019). Cassava is grown in more than 105 counties; Nigeria, Democratic Republic of the Congo, Brazil, and Indonesia are the leading cassava producers. Cassava fresh root yields under smallholder farmer conditions have been estimated about 1-10 $\mathrm{t}$ $\mathrm{ha}^{-1}$. However, fresh root yields can potentially reach $75-80 \mathrm{t}$ $\mathrm{ha}^{-1}$ through the use of high yielding, best adapted cultivars and improved crop management practices (Anikwe and Ikenganyia, 2017).

Cassava production has shown a steady growth for the last six decades. The most dramatic increase in Africa and Asia were observed from 1996 to 2017 (Figure 1A). Cassava production in Latin America, on the other hand, showed more moderate increases. The large increase in cassava production can be attributed partly to an increase in area harvested in Africa as farmers recognize the economic importance of the crop (Figure 1B) and partly due to a substantial yield gains in Asia due to new improved cultivars and improved agronomic practices (Figure 1C) (Aye and Howeler, 2017). Cassava production and the demand for cassava are expected to grow largely because of the crop's ability to withstand drought and provide reasonable yields on marginal and low-fertility soils. Many countries have realized the economic potential of the crop as a food, feed, and 


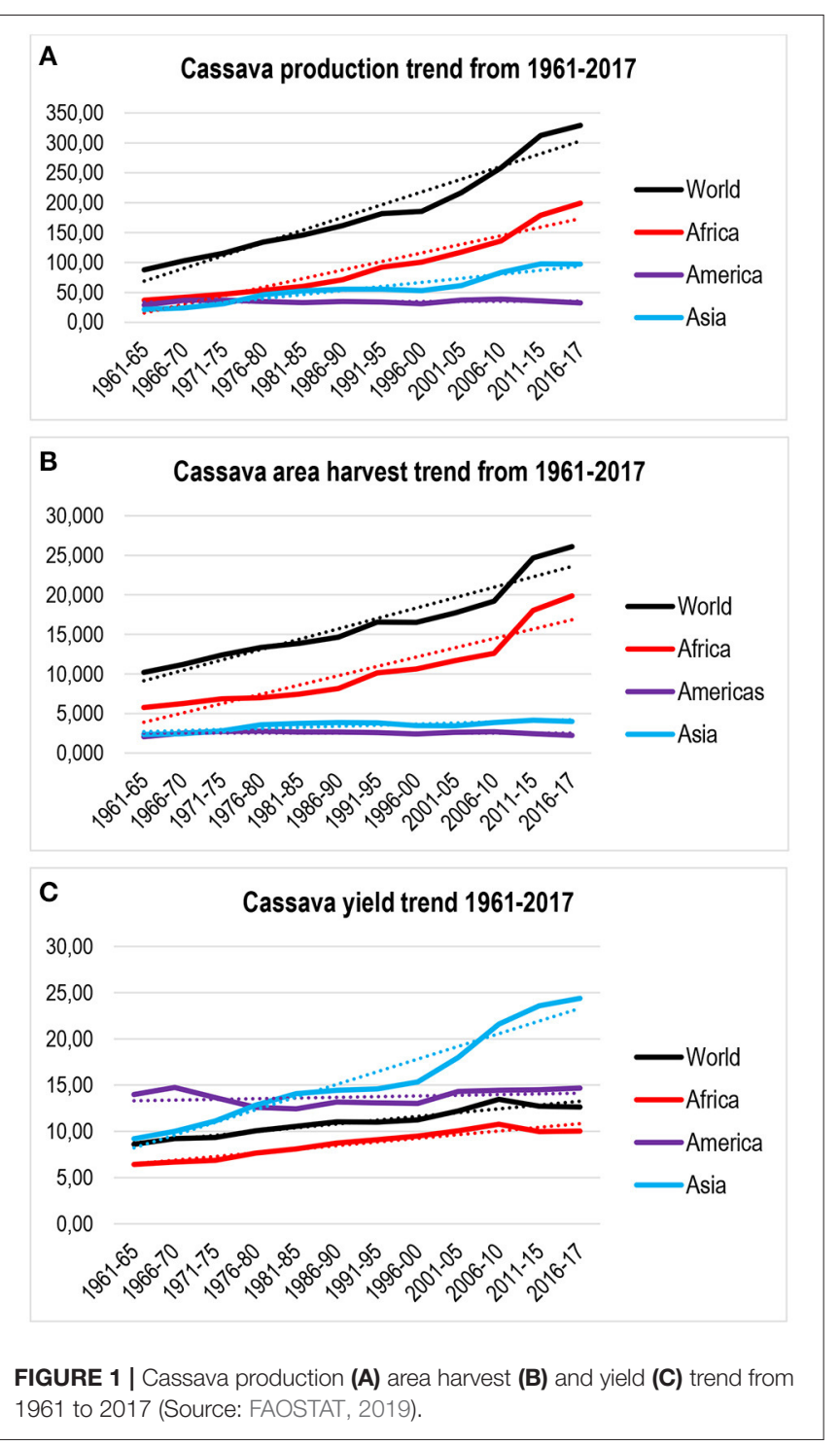

industrial crop. In Africa, the demand for cassava production has been driven by its food applications, while in Asia the demand has been driven by its industrial applications for starch, livestock feed and biofuel production.

Although cassava has had a long history in the rest of Africa, its production in South Africa is a recent development, arising with the advent of production of high-quality industrial starch from cassava on an industrial scale. In South Africa, cassava is produced on a few commercial farms of $<5,000$ hectares and in small fragmented areas, with limited technologies and under low input farming system (Bunce, 2019). It is grown as a secondary crop by smallholder farmers and is utilized for the production of commercial and food grade starch. The sub-sector is dominated by disease-prone varieties with long maturation periods of more than 18 months, and low yield potential. However, cassava farming is becoming more attractive due to the diverse use of cassava products in the country and the diminishing potential of other crops such as sugar cane.

\section{CASSAVA UTILIZATION}

\section{Cassava as Food Security Crop}

Cassava is an important root crop and is a source of dietary energy to over 700 million people in the tropical and subtropical Africa (Prochnik et al., 2012). Cassava is the fourth most important source of calories in the developing world after wheat, maize, and rice. More than $40 \%$ of Africa's population consume cassava as a staple food, and it is the second most important crop after maize (FAOSTAT, 2019). The roots and leaves are the two most valuable parts of the mature cassava plant that can be used as a food source (Morgan and Choct, 2016). Cassava is grown primarily for its enlarged storage roots, which are consumed as food for humans in various forms (Chandrasekara and Kumar, 2016). Cassava roots are rich in carbohydrates and are a good source of energy, a moderate source of minerals and vitamins, and a poor source of proteins (Montagnac et al., 2009). In particular, cassava is a good source of Vitamin C, thiamine, riboflavin, and niacin (Montagnac et al., 2009). Cassava has the potential to produce and store more carbohydrate per unit area under production than any other major grain and root crops (ElSharkawy and De Tafur, 2010). Cassava roots can be converted into many food products, such as chips, pellets, pasta, flour and starch, with good storability and relatively low postharvest losses (Adelekan, 2010). The nutritious leaves can also be harvested for human consumption as a green vegetable (Montagnac et al., 2009) and for animal feed (Lukuyu et al., 2014). The leaves are rich in iron, calcium, vitamins, and a good source of proteins (Montagnac et al., 2009).

Cassava storage roots can be stored in the ground for up to 2 years after maturity, and can be harvested at any time of the year when a farmer needs food (Sanchez et al., 2013). The natural high storability of cassava compared to other root crops provide farmers the opportunity to capitalize on the best market opportunities (Hershey et al., 2012). Farmers can plant and harvest cassava without any capital input on marginal lands where other crops cannot be produced. Cassava is grown predominantly by small-scale farmers with limited resources on marginally fertile soils (Kintché et al., 2017). The low input land use systems (also commonly referred as small-scale agriculture), which they operate on a sustainable basis is of great benefit to resource poor farmers and to the eco-system (Altieri et al., 2012). Consequently, cassava is considered as an excellent food security crop and a household food bank that can be drawn anytime when adverse climatic conditions limit the production of other crops (Nakabonge et al., 2018).

However, high cyanide content, poor protein, and micronutrient content, and pest and disease issues are the major problems in using cassava as a food crop. Serious malnutrition problems have been reported in countries that rely primarily on cassava food products, with little or no protein supplements (Akinola et al., 2020). Micronutrient deficiencies present in some staple food crops have been improved via bio-fortification (Bouis and Saltzman, 2017). Cassava has been targeted for bio-fortification because of its unique geographical distribution (Talsma et al., 2016). There is considerable potential for enhancing the nutritional value of cassava through breeding. 
Variation in cassava for carotene content (Ceballos et al., 2017), protein content (Carvalho et al., 2019), and micronutrient content (Burns et al., 2012) have been reported in the available cassava germplasm collections.

Although South Africa is often characterized by food selfsufficiency at national level, about $20 \%$ of the households' experience food insecurity, malnutrition, unemployment and poverty (Abdu-Raheem and Worth, 2011). The fact that cassava's ability to grow and provide reasonable yield in areas where environmental conditions and per capita resource levels are declining makes it an ideal candidate to be a food security crop. In addition, most South Africans have a relatively monotonous dietary system, mainly based on maize and bread starch, and protein such as chicken and milk. Diversification of the crop base that require low agricultural input such as cassava will improve food and nutrient security at a rural household level. Hence, cassava can stabilize food security by providing food for many households and serving as a cash crop as a source of industrial starch in South Africa. In South Africa, the role of cassava as food security crop needs to be viewed from dual perspectives; first through its direct contribution to household food security and second indirectly by being cash crop through raw material sold to the starch industry. Hence, discussing the industrial application is unavoidable while elaborating the role of the crop on food security.

\section{Cassava as Climate Smart Crop}

Global climate change and its impacts have been observed and reported (Miller, 2008). Changes in precipitation amount and patterns, temperature, atmospheric carbon dioxide level and water availability are indicators of climate change (World Bank, 2008). The global mean temperature has increased by $\sim 0.74^{\circ} \mathrm{C}$ over the last century (Miller, 2008) and $1.1^{\circ} \mathrm{C}$ by 2020 . In some locations, an increase in the number of extreme hot days and a decrease in the number of extreme cold days have been observed (Singh and Singh, 2012). Likewise, changes in the intensity and patterns of precipitation have been witnessed as the Mediterranean region, southern Africa, and southern Asia had a decline in precipitation, whereas northern Europe, northern and central Asia, and the eastern portions of North and South America had an increase in precipitation (IPCC, 2007). These affect the length of crop growing period, development and yield (Cai et al., 2009). The climate change impacts on agriculture are unavoidable, hence implementing climate adaptation strategies are crucial to mitigate the negative impacts of climate change.

South Africa is a water scarce country where only $12 \%$ of its land are suitable for crop production (Donnenfeld et al., 2018). Most of South Africa's land surface (69\%) is suitable for grazing and livestock farming. South Africa uses about $60 \%$ of its scarce water resources on irrigation to grow crops such as maize, potato, wheat, sugar cane, and sunflower (Baleta and Pegram, 2014). Climate change poses a significant risk to South Africa's water resources, food security, health, infrastructure, ecosystem functions, and biodiversity (Ziervogel et al., 2014). In South Africa, climate change projections have suggested that by 2050 mean national temperatures will increase by $5-8^{\circ} \mathrm{C}$, with much reduced rainfall in the west and south of the country, and an increased risk of heavy rainfall events in the eastern parts of the country (Calzadilla et al., 2014). These will result in changes in rainfall patterns, evaporation rates, temperature ranges, reduced crop yields, and the emergence novel pests and diseases of crops and livestock (Calzadilla et al., 2014).

In addition to climate change, a decline in land quality due to soil degradation, soil acidification and land competition has dramatically increased the challenge of achieving national food security. Expanding the area of available arable land is not possible due to demographic pressure, urbanization and expansion of industries (Naab et al., 2013). Agricultural intensification has often been considered as the primary approach to meet the rising food demand. Enormous gains in agricultural production have been achieved due to agricultural intensification through rigorous utilization of fertilizers, pesticides, and irrigation (Mateo-Sagasta et al., 2017). The widespread application of synthetic fertilizers has generated varying degrees of soil acidification, groundwater contamination, and ecological degradation of the available arable land (Khan et al., 2018). Similarly, the worldwide chronic illness such as reproductive and birth defects, neurotoxicity, kidney and liver damage, high prevalence of cancer, and the emergence of more virulent strains of diseases and pests are related to excessive use of synthetic agrochemicals (Mossa et al., 2018). In South Africa, the commercial sector relies heavily on the use of irrigation, fuel, synthetic fertilizers, pesticides, and herbicides. Moreover, relatively few crops have occupied the major production areas and grown repeatedly year after year.

Climate change coupled with ecological degradation and water scarcity has curtailed food productivity, availability, accessibility, and quality at the national level. The above factors also aggravate the emergence of novel pests and diseases (Jones and Barbetti, 2012). The contemporary arrival of the fall army worm, which has destroyed maize, wheat and potato crops across Africa and Asia, is one of the negative impacts of climate change observed in South Africa (Amusan and Olawuyi, 2018). To ensure that the agricultural sector continues to play an important role in the economy, sustainable agro-ecological solutions should be implemented (Wezel et al., 2018). The implementation of ecosystem-friendly, sustainable agricultural practices such as crop rotation and sequencing, integrated pest management, efficient water management, crop and varietal diversification and the use of well-adapted improved varieties are obligatory. Cassava is drought resistant and resilient to climatic changes, high temperatures, and poor soils, which makes it an important crop for the twenty-first century (Mupakati and Tanyanyiwa, 2017).

\section{Cassava as Potential Bio-Fuel Feedstock}

More than $90 \%$ of South Africa's primary energy is derived from fossil fuels that constitute $80 \%$ of the country's greenhouse gas (GHG) emissions (STATS-SA, 2018). About 77\% of South Africa's energy needs are directly derived from coal, and $92 \%$ of coal consumption on the African continent is produced in South Africa (Baker, 2017). The heavy dependence on coal in South Africa is not only because coal is a relatively cheap source of energy, but also because South Africa has abundant reserves 
TABLE 1 | Comparison of bioethanol production from different energy crops.

\begin{tabular}{lccc}
\hline Crop & $\begin{array}{c}\text { Yield } \\
\text { (tons/ha/year) }\end{array}$ & $\begin{array}{c}\text { Bioethanol conversion } \\
\text { rate (L/ton) }\end{array}$ & $\begin{array}{c}\text { Bioethanol yield } \\
\text { (L/ha/year) }\end{array}$ \\
\hline Sugarcane & 70 & 70 & 4,900 \\
Cassava & 40 & 150 & 6,000 \\
Sweet sorghum & 35 & 80 & 2,800 \\
Maize & 5 & 410 & 2,050 \\
Wheat & 4 & 390 & 1,560 \\
Rice & 5 & 540 & 2,250 \\
\hline
\end{tabular}

Source: Wang (2002)

(STATS-SA, 2017). Fossil-based transportation fuels have been recognized as the largest contributor toward GHG emissions (Perera, 2018). Many countries ratified the Paris Agreement to reduce annual global greenhouse gas (GHG) emissions to between 30 and $50 \%$ by 2030 to prevent a global temperature rise (Shepherd and Knox, 2016). South Africa has also endorsed the Paris Agreement, and committed to reduce the contribution of coal-generated power from $82 \%$ in 2016 to $31 \%$ in 2050, as outlined in the Integrated Resource Plan (IRP) of 2016. Further, much of the national budget is spent on fossil fuel; hence, there is a growing commitment to explore alternative energy sources such as the use of renewable energy and the conversion of biomass to bioenergy (Petrie, 2014). The increase in the price of fossil fuel, coupled with the need to reduce greenhouse gases emissions, have driven the search for renewable sources of fuels.

Bioethanol production requires a highly productive, sustainable supply of feedstock, and appropriate processing technology. Cassava, apart from its traditional role as a food crop, is recognized as a potential feedstock crop for the production of bioethanol (Marx, 2019). Cassava is an excellent feedstock for ethanol production: it is adapted to a wide range of growing conditions, especially to marginal environments; it can be planted and harvested all year round; and cassava can be stored as dried chips before processing (Nguyen, 2007). Bioethanol can be produced from cassava either from storage roots or the cassava waste stream. Cassava storage roots, on average contain about $35 \%$ dry matter content, with a starch content of between 70 and 85\% (Benvenga et al., 2016). Wang (2002), in his studies of bioethanol production potential of six energy crops, reported that the annual yield of bioethanol from cassava is significantly higher than from other crops (Table 1). Yang et al. (2017) achieved an ethanol yield of $0.9 \mathrm{~g}$ ethanol/L/h through a combination of aerobic and anaerobic fermentation processes, while Wang et al. (2017) reported an ethanol yield of $11.43 \%(v / v)$. Marx and Nquma (2013) achieved a final ethanol yield of $530 \mathrm{~L}$ of ethanol per ton of unpeeled cassava roots, which translated into 2,400 L/ha.

Cassava wastes are also a potential source of bioethanol and organic fertilizer (Ekop et al., 2019). Cassava waste includes leaves, stems, pulp, fiber peels and sub-standard tubers that can be used as ethanol feedstock. The peels and stems comprise of $28 \%$ of the total dry matter and can generate more than $60 \%$ ethanol, indicating the potential use of cassava wastes for ethanol production (Nuwamanya et al., 2012). Elemike et al. (2015) also reported that, depending on the starch-to-ethanol process, cassava wastes can have a starch content as high as $60 \%(\mathrm{w} / \mathrm{w})$.

\section{Cassava as a Potential Industrial Crop}

Cassava is the fourth most important source of plant-based starch in the world after wheat, maize, and potato (Sharma et al., 2016). The global demand for cassava starch is projected to be over 10 million tons by 2024 (Business wire, 2019). Technological advancements in the starch industry makes cassava an attractive source of modified starch such as food grade starch, and adhesive, paper, and textile grade starches (Adelekan, 2010). Cassava is thus considered to be a highly valuable industrial crop for the world today and in the future.

In South Africa, maize is currently the main crop used for food (37.4\%), feed (39.8\%), exports (17.9\%), and industrial purposes (4.8\%). It constitutes two-third of the commercial area planted in field crops, with an average annual production of $\sim 10-12$ million tons (Greyling and Pardey, 2019). Maize is the source of about 95\% of the local starch produced in South Africa. Competition between industries utilizing maize products has resulted in the failure of the local starch industries to meet the starch demand of the country. Hence, South Africa imports around 66,000 tons of starch products annually, of which more than $33 \%$ is cassava (tapioca) starch (UN Comtrade, 2019). Although South Africa's starch import volumes experienced positive and negative growth patterns during the period 2008-2017, cassava starch import volumes have consistently been higher than those of maize, wheat and potato (Figure 2). If cassava can be used as an alternative starch source to satisfy the domestic starch demands, this will reduce competition among staple food commodities and reduce the volumes of imported starch.

Cassava storage roots contain a starch content that is about $40 \%$ higher than rice and 25\% more than maize (Tonukari, 2004). Cassava starch is the cheapest and preferred known form of industrial starch, including in South Africa (Figure 2). The estimated demand for cassava starch alone in 2004 was 20,000 tons per annum; this demand would require more than 300,000 tons of cassava for milling and about 26,000 hectares of land under cassava production. Grasping the industrial potential of cassava in the starch industries and setting up rural cassava producers will create sustainable income sources and improve the livelihoods of rural community. Cassava starch also fetches a higher price on the market than maize, potato, and wheat starch. South Africa spends more than R40 million annually to import various starches, of which $17 \%$ is for cassava starch (UN Comtrade, 2019). The country imports most of the cassava starch from Asia and a small portion from the USA (IDC, 2017). Producing industrial starch from cassava locally will satisfy local starch demands, avoid competition among staple food commodities, relieve the country's economy from foreign currency strains, and reduce import volumes.

The largest exporters of cassava are not necessarily the largest producers. Although Africa is the leading cassava producer globally, most of the cassava crop is consumed domestically and considered as a non-trade commodity. Nigeria, the DRC, Brazil and Indonesia are the top producers of cassava globally. 


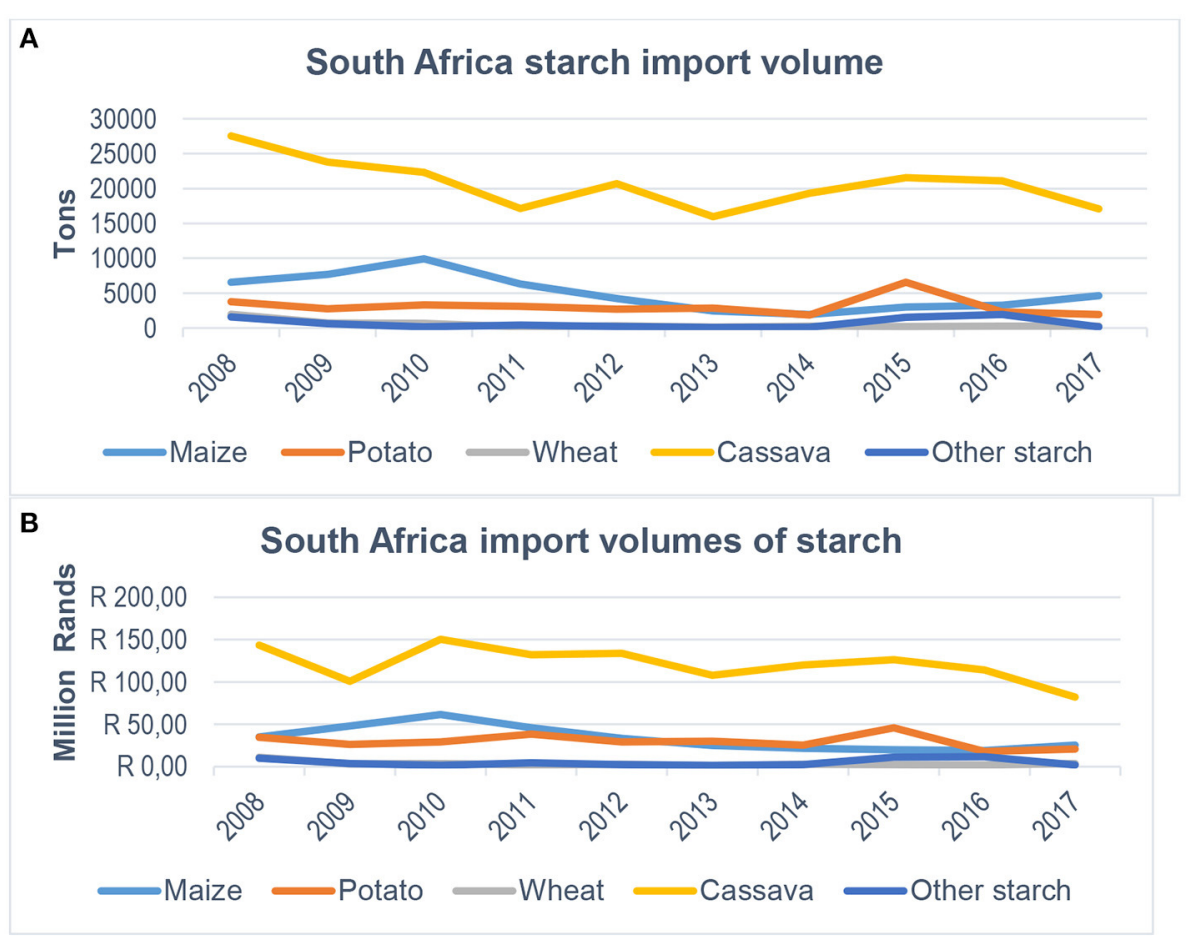

FIGURE 2 | (A) Starch import volumes into South Africa and (B) South Africa's import volumes of various starches (Source: Commodity Trade Statistics Database, United Nations Statistics Division, 2020).

Despite attempts to promote cassava as a commercial crop in Africa, low international prices for maize starch has made cassava starch production in Africa unattractive. Asia is driving the world trade in cassava starch, with Thailand at the top of the ladder, followed by Vietnam, Germany, and China (Table 2). At the beginning, European countries were the only cassava importers. However, imports of cassava products by nonEuropean countries expanded in the mid-1980's mainly because other markets were developed in Asia (Otekunrin and Sawicka, 2019). Presently, China, USA, France, and Germany are the top cassava importers (Table 3). Two-sample $t$-test analysis was made to compare the differences between the changes estimated over the categorical times. There was a significant change $(p=0.05)$ in export volume between the period 2010-15 and 2015-17. South Africa sources its cassava supplies mainly from South East Asia. However, with appropriate investment, planning and policy support, this situation could be reversed.

\section{Role of Cassava in the Development of Smallholder Farmer Community}

Agriculture in South Africa has a dual character (Gwebu and Matthews, 2018), which comprises of relatively few welldeveloped commercial farms and a large number of small scale, subsistence farms. The commercial sector is mainly based on capital intensive, export oriented and large-scale production. They produce about $90 \%$ of the total agricultural production and their farms cover about $86 \%$ of the country's cropland. Subsistence farming, on the other hand, relies on traditional production methods and is labor intensive, employing about $86 \%$ of the total farm labor (Pienaar and Traub, 2015). Smallscale farmers mainly produce for household subsistence. Cassava provides an opportunity to improve smallholder farmers' income and food security by unlocking economic value, by opening up marginal lands for cultivation and pooling communal resources in addition to commercial operation by organized farmers groups to enable mechanization.

Cassava is a labor-intensive crop that requires lots of labor from planting to processing. Hence, it can provide employment opportunities to unskilled labor in rural areas. Moreover, cassava is a bulky and highly perishable crop that needs to be processed before it is transported, which opens up opportunities for small-scale farmers to be involved in producing semi-processed materials and simple value-added products, for greater economic gains derived from marginalized or nutrient poor land. Developing the cassava industry in South Africa could play a role in transforming smallholder sector into small- and medium- sized enterprises by engaging them in distributing better quality planting materials, implementing intensive cassava production and establishing community-based primary processing systems. Establishment of small-scale farmer development programs will ensure sustainable productivity and profitability of cassava production for small scale and emerging farmers. These initiatives could be used to drive the economic empowerment of small scale and emerging farmers through meaningful integration with the secondary processing industries. This will be achieved through partnerships that create an 
TABLE 2 | World top leading starch exporters (in ton).

\begin{tabular}{|c|c|c|c|c|c|c|c|c|c|}
\hline \multirow[t]{2}{*}{ Country } & \multirow[t]{2}{*}{2000} & \multirow[t]{2}{*}{2005} & \multirow[t]{2}{*}{2010} & \multirow[t]{2}{*}{2015} & \multirow[t]{2}{*}{2017} & \multicolumn{4}{|c|}{ Changes (\%) } \\
\hline & & & & & & 2000-05 & 2005-10 & 2010-15 & 2015-17 \\
\hline Thailand & 980,300 & $1,560,423$ & 1,873,686 & $3,185,130$ & $3,136,244$ & 37 & 17 & 41 & -2 \\
\hline Vietnam & 89,436 & 344,747 & $1,080,648$ & $2,200,250$ & 682,702 & 74 & 68 & 51 & -222 \\
\hline Germany & 535,745 & 473,129 & 208,737 & 535,676 & 552,285 & -13 & -127 & 61 & 3 \\
\hline China & 74,934 & 179,911 & 422,509 & 87,716 & 285,972 & 58 & 57 & -382 & 69 \\
\hline Netherlands & 391,108 & 317,126 & 306,249 & 168,756 & 151,015 & -23 & -4 & -81 & -12 \\
\hline Spain & 73,154 & 37,618 & 127,324 & 153,538 & 150,906 & -94 & 70 & 17 & -2 \\
\hline USA & 234,480 & 222,405 & 201,706 & 108,644 & 131,306 & -5 & -10 & -86 & 17 \\
\hline France & 95,551 & 129,496 & 102,350 & 77,270 & 79,713 & 26 & -27 & -32 & 3 \\
\hline Korea & 68,802 & 62,067 & 104,292 & 63,597 & 49,728 & -11 & 40 & -64 & -28 \\
\hline South Africa & 44,996 & 38,492 & 35,919 & 32,847 & 30,248 & -17 & -7 & -9 & -9 \\
\hline
\end{tabular}

Sources: FAOSTAT (2019).

TABLE 3 | World leading starch importers (in ton).

\begin{tabular}{|c|c|c|c|c|c|c|c|c|c|}
\hline \multirow[t]{2}{*}{ Country } & \multirow[t]{2}{*}{2000} & \multirow[t]{2}{*}{2005} & \multirow[t]{2}{*}{2010} & \multirow[t]{2}{*}{2015} & \multirow[t]{2}{*}{2017} & \multicolumn{4}{|c|}{ Changes (\%) } \\
\hline & & & & & & 2000-05 & 2005-10 & $2010-15^{\star}$ & $2015-17^{*}$ \\
\hline China & 151,520 & 609,576 & 979,658 & $2,081,646$ & $2,572,161$ & 75 & 38 & 53 & 19 \\
\hline USA & 145,702 & 165,885 & 196,854 & 317,213 & 337,441 & 12 & 16 & 38 & 6 \\
\hline France & 167,104 & 155,503 & 180,621 & 187,753 & 264,783 & -7 & 14 & 4 & 29 \\
\hline Germany & 186,969 & 282,068 & 346,557 & 413,702 & 258,495 & 34 & 19 & 16 & -60 \\
\hline Netherlands & 87,728 & 109,305 & 172,681 & 226,338 & 255,908 & 20 & 37 & 24 & 12 \\
\hline UK & 168,083 & 177,042 & 224,162 & 238,037 & 254,524 & 5 & 21 & 6 & 6 \\
\hline Poland & 6,169 & 38,822 & 110,897 & 177,642 & 160,129 & 84 & 65 & 38 & -11 \\
\hline Indonesia & 162,607 & 623,328 & 921,862 & 686,561 & 136,201 & 74 & 32 & -34 & -404 \\
\hline Malaysia & 136,201 & 187,332 & 298,305 & 291,064 & 91,632 & 27 & 37 & -2 & -218 \\
\hline Belgium & 96,373 & 126,758 & 98,212 & 120,065 & 59,318 & 24 & -29 & 18 & -102 \\
\hline South Africa & 11,776 & 32,296 & 32,087 & 35,484 & 28,163 & 64 & -1 & 10 & -26 \\
\hline
\end{tabular}

Sources: FAOSTAT (2019).

*Significant different at 5\%.

enabling environment by closing all gaps in the value chain. The source of the innovative technologies for technology diffusion and deployment will be the developmental funding institutions as well as research councils.

\section{THE NATIONAL CASSAVA R\&D STRATEGY: BACKGROUND ON STRATEGIC IMPERATIVES}

In South Africa, the agricultural sector is expected to play a vital role in alleviating food insecurity, poverty, malnutrition, and unemployment, while protecting the ecology. Agricultural R\&D strategy has serious implications on the way agricultural research is designed, implemented, evaluated, disseminated, and utilized to generate innovations. In the twenty-first century, agriculture remains fundamental for poverty reduction, economic growth, and environmental sustainability in developing countries (World Bank, 2008). Although the scientific methods of doing research have not been changed substantially since the nineteenth century, the environment within which the discovery and innovation occurs changes constantly. Rapid changes have been taking place in the institutional landscape, global economy, farming sector, social structures, and the global and local food industries (Anandajayasekeram, 2011). That is why a constant revision of the R\&D strategy of the ARC and that of the country will remain imperative, with respect to emerging challenges and societal needs, and integrating the R\&D with the value chain. By taking the below key considerations into account, the ARC, in consultation with role players, developed a cassava R\&D strategy. The components of the cassava R\&D strategy include; germplasm acquisition, evaluation, conservation and breeding, agronomy, crop protection, socioeconomics, food science, postharvest and storage, mechanization, and agro-processing thematic areas.

\section{Important Considerations in the Crafting of the R\&D Strategy Agricultural Sector}

South Africa has $\sim 35,000$ largely white, highly capitalized commercial farmers and around 2.9 million black subsistence 
farmers (Aliber and Hart, 2009). The commercial sector is producing around $95 \%$ of the country's agricultural produce on $86 \%$ of total agricultural land, while the smallholder sector is farming on $14 \%$ of agricultural land (Aliber and Hart, 2009). The smallholder sector is characterized by low productivity, labor-intensive cultural practices, use of traditional production techniques, and poor institutional support, largely (Louw, 2013). The smallholder sector has been neglected in terms of the distribution of economic assets, support services, market access, infrastructure, and income (Pienaar and Traub, 2015). The development of an appropriate R\&D strategy that addresses food security, malnutrition, inclusion of smallholder farmer sector and unemployment has been given the highest priority within the ARC.

\section{Climate Change}

Climate change and agriculture have significant impact on each other. Climate change has a massive impact on all forms of agriculture. Agriculture contributes to climate change through greenhouse gas emissions and changes in land use such as deforestation. There is an urgent need to recognize the risk posed by climate change in agriculture and vice versa. In case of subsistence farmers, the risks are high: due to their high exposure and vulnerability to natural hazards; their dependence on rainfed agricultural production systems; and their limited capacity to ameliorate stresses induced by climate change. As a result, climate change will increase their vulnerability, and exacerbate levels of food insecurity and malnutrition. Several climate adaptation strategies have been suggested to address the gradual impact and risk of climate change. Adoption of climate smart agricultural techniques and job creation in rural communities to increase resilience and to contribute to more sustainable food systems have been given top priorities among the adaptation strategies. To this effect, a holistic and comprehensive R\&D strategy, cutting across various disciplines, is necessary to harmonize the relationship between climate challenge and agriculture.

\section{Organizational Structure}

According to the United Nations estimates, the current global population is 7.7 billion, and this is expected to reach 10 billion by 2050 . Consequently, it has led to increases in food demand and consumption, and will keep undermining food insecurity in Africa. Both national and international agricultural research institutions should be strengthened and capacitated to leverage the global demand for food and nutrition. Suitable approaches should be designed to increase the efficiency, productivity and profitability of the agricultural sector. Many studies in the past indicated that a combination of institutional reorganizations and other productivity enhancing strategies, such as the use of improved inputs, mechanized production techniques and improved management practices, are required to increase production efficiency (Abass et al., 2013). Market and credit access, meaningful linkage between producers and processers, diversification of use in various manufacturing sectors, practical training, and high market information flow to relevant stakeholders will help move the sector toward true commercialization.

\section{Market}

Agricultural commodity and input prices are likely to increase substantially, resulting in changes to the structure and behavior of the agricultural global market and its competitiveness. Future developments in South African agriculture lie primarily on greater technical efficiency, exploring niche markets and valueaddition within the established commercial sector, together with improving the productivity of the smallholder sector. Some countries have develop their cassava value chain exclusively for food consumption, and others exclusively for industrial applications. For example, cassava production in Africa and Latin America is mainly driven by food security motives, whilst in Asia it is driven by industrial application, as the primary feedstock for starch and ethanol production. Although cassava has huge potential in Southern Africa, the major challenge for cassava cultivation is access to markets and creating interest in new market opportunities. However, the existing market for cassava products in Southern Africa signals the high potential for growth in industrial starch production locally. Market signals serve as an incentive for investment by the private sector (Abass et al., 2013). There are some encouraging and positive initiatives on the utilization of cassava by the starch industry. Some concrete examples are given below.

Mondi South Africa is an enterprise that aims to encourage long-term economic empowerment and job creation by developing small businesses in Mondi's forestry value chain and surrounding communities. The company has identified the potential for planting cassava on a commercial basis, which would create an employment opportunity for people within the rural communities of the Mondi Forests area. They currently producing 15000 tons of cassava starch annually, with the industry usage sitting at 25,000 tons (Maema Obakeng, personal communication).

Tongaat Hulett Starch is Africa's largest producer of highquality starch, glucose and related products. They produce starch for local and international markets across Africa and around the world using maize as a raw material. They are interested in exploring cassava starch as a raw material to exploit potential cost saving benefits due to cassava starch's unique functional properties. They have also expressed their interest by funding cassava research projects conducted at WITS University.

Some of the world's largest alcohol beverage making companies are finding ways of tapping into the potential of cassava. Both SABMiller and Diageo have launched commercially made cassava-based beers in Africa over the past 2 years. SABMiller PLC (now called AB InBev) has launched two cassava beers in Africa, Eagle (Ghana), and Impala (Mozambique). The main objective is to source raw materials from local farmers mainly to reduce costs whilst contributing to rural economic development. They are committed to expand the initiative, the business and financial models developed for the rollout of the brewing facilities in other African countries. Similarly, National Starch is a global ingredient solution company aiming to deliver the high-quality ingredients that give sweetness, texture and nutrition for the food, beverage and brewing industry. Their local subsidiary has shown interest in sourcing cassava starch for their multinational client base. 
PhilAfrica foods was established to transform the lives of millions of Africans economically and socially through food processing in Africa. Dadtco PhilAfrica, a Pan-African cassava processor, is a mobile starch processing company that produce high-quality wet and dry starch flour for primary use in the baking and brewing industries. They source raw materials directly from smallholder farmers in rural regions of sub-Saharan Africa, thereby significantly impacting the lives of thousands of farmers and their families.

Unilever, the Anglo-Dutch consumer goods company, is targeting cassava root to make sorbitol, a key ingredient in toothpaste and other products. Their target is to improve their local procurement content by sourcing the sorbitol locally.

The potential of cassava in animal feed has been studied extensively by researchers worldwide. Most parts of the cassava plant such as roots, stems and leaves can be used for animal feed. The major problems of cassava roots restricting its use in animal feeds are its low amylose content and protein content (0.5$1.7 \%)$, compared to other starch crops. However, the high-energy value of cassava makes it an attractive carbohydrate ingredient in animal diet (Morgan and Choct, 2016). There should be a market for cassava products in the existing domestic market for animal feeds in South Africa. The leaves are high in carbohydrate and protein $(17 \%)$, and thus they can be used as a potential substitute for soybean cake, alfalfa, or maize.

\section{The Roles of Private and Public Sectors}

The role of private and public sector needs to be well-defined and this will facilitate commercialization of crop technologies from public sector research. The ARC initiated a process to coordinate the cassava $R \& D$ in South Africa in light of the growing importance of the crop, and the lack of coordination among the various stakeholders. Several stakeholder engagements have been made, aimed at mapping the way forward for cassava $R \& D$ and commercialization of the crop in South Africa. During the various stakeholder meetings, aspects such as the opportunity and challenges of cassava research, available resources in terms of manpower and research funds, promotion and adoption of the crop and policy issues that need to be addressed were raised and discussed. The stakeholder forum discussed the need for an integrated approach with strategic partnership between the public and private sectors. This can be realized through close linkage between producers, starch-processing industries, farmer support programs, financial institutions and agricultural research institutions along the cassava value chain. Similarly, collaboration among governmental organizations would aim to share resources and to make an enhanced impact on food and nutrition security, and to increase production, productivity, profitability, and environmental stability, and to stimulate job creation.

The ARC was given the assignment to assess the current research capacity for supplying high-quality planting material and farmer-based small-scale production of cassava tubers for commercialization of the crop. The ARC was also tasked to drive the policy initiative to develop an evidence-based policy that will facilitate the equitable economic exploitation of the crop. The Technology Innovation Agency (TIA) agreed to explore the industrial potential of the crop and to assess the availability of financial resources to support essential cassava research programmes. It is envisaged that these initiatives will produce the required result in developing a viable starch industry underpinned by sustainable primary production supported by strong R\&D. Previous studies had been undertaken with the objective of establishing cassava as a source of industrial starch, most of which failed. The TIA- led initiative was constructed to mitigate the shortfalls of these prior studies, namely to access diverse, disease-free cassava material germplasm; to screen the germplasm in multiple geographic regions over multiple seasons and using the data from these cultivar assessments to determine the feasibility of adopting suitable cultivars by small scale or emerging farmers in a pooled communal set-up. The study will provide the starting point for a local breeding program to develop superior cassava cultivars for South Africa.

\section{Alignment With Regional and International Research Community}

Globally, cassava is recognized as an important food and industrial crop. The International Institute of Tropical Agriculture (IITA), International Center for Tropical Agriculture (CIAT), National Agricultural Research Institutes (NARs), and Universities in Africa have played leading roles in cassava improvement. The production, characterization and product development from cassava is at its infancy in South Africa compared to other African countries. It is vital that South Africa taps into the skills and advanced $R \& D$ programs of these institutions by establishing strong collaborative links. Capacity building can be done through fellowships, grants schemes, exchange and partnership programmes. Collaborative research in terms of information access, germplasm exchange and genotyping of elite germplasm should be imperative. In addition, to enhance the local knowledge base of cassava, formal training through postgraduate studies and informal trainings such as awareness creation among stakeholders and field days would be important.

\section{DRIVERS OF THE CASSAVA INDUSTRY IN SOUTH AFRICA}

\section{Farmer Production System Training}

The UN Conference on Trade and Development released a Policy Brief in 2010 suggesting that: "In the Twenty-first century, transforming the existing industrial-agricultural systems into knowledge- and labor-intensive rather than agro-chemical and energy-input-intensive is necessary" (Trade Development Report, 2010). The transformation should consider integration of local knowledge with modern agricultural techniques, giving strong emphasis to the available biodiversity and resources. A Trade Information Brief (TIB) for the Southern Africa Development Community (SADC) (2015) proposed cassava as a potential industrial crop for SADC's farmers. Although cassava has not been a traditional commodity in South Africa, exploiting cassava's potential for food, industrial starch and renewable energy will improve the livelihood of many farmers at a household level. Training is an integral part of any development activity and 
a process by which acquiring new knowledge, skills, practices, and attitude in the context of preparing farmers for improving agricultural productivity (Pandey et al., 2015). Training plays a key role in human capacity development, to equip farmers with skills, knowledge and competencies for sustainable crop production, resource utilization, and income generation (Yaseen et al., 2015). Therefore, adequate training on cassava production, processing and marketing is essential for farmers to acquire the necessary knowledge and skills to exploit the full economic potential of the crop. Accredited training modules in cassava production and processing, as well as financial and business management, will be developed. Production enterprises will have to be established and supported to enable farmers to produce and partially process products for the starch processing market.

\section{Awareness Creation and Promotion of the Crop}

The local production of the staple commodities such as maize, wheat and potato is affected by recurrent and severe droughts. Exploring alternative climate resilient solutions have become a priority. Awareness creation of the prevailing environmental conditions and the available mitigation strategies are imperative. As part of awareness creation, organization of symposia, conferences and workshops, at which researchers from local and international institutes can present their research findings on cassava should have a significant impact. These conferences can serve as essential forums to inform key policy makers, farmers, growers and processors to access first-hand information from experts in countries where cassava is a major crop. Funds should be accessed from national and international institutions. Furthermore, the use of a promotional hub is vital to introduce various cassava products to researchers, policy makers, producers, and processors to appreciate the economic importance of the crop.

\section{Development of Suitable Business Model}

The social enterprise model is a corporate model that addresses the social, environmental and economic aspects of any commodity development. In this model, the farmers are organized in a way that they play a key role in leading the primary production aspect, but are also stakeholders of downstream processing. The primary objective of the social enterprise model is to make farmers involved beneficiaries across the entire value chain. It is critical to develop the whole value chain in such a way it sustains itself and empowers farmers. One of the merits of this model is that it is socially viable as the majority of the society around the production area benefits from an environmentally sustainable production system. Second, cassava, being a multi-purpose crop, has production, processing and marketing components that provide job opportunity to the smallholder farmers across all the value chain. However, there is no example of feasible and successful agricultural social enterprise in South Africa that can be used as a model. However, it has been used successfully in other sectors such as education and training, according to a study done by the Gordon Institute of Business Sciences at the University of Pretoria (GIBS, 2018).

\section{The Role of Commodity Organization}

A commodity-based organization represents the entire value chain such as growers, consumers, processors, traders, importers, exporters, input distributers, and transporters. These types of organizations can play important role in promoting the particular interests of their members and advocating policy and regulatory changes. The South Africa cassava industry association (CIASA) was established under the Department of Trade, Industry and Competition (DTIC) to address and coordinate all aspects of the cassava value chain (IDC, 2017). Presently, even though CIASA attempts to be proactive, it was not be able to coordinate cassava research or the development of a cassava value chain in South Africa. The association was probably established too soon, when there was a lack of critical mass and political support. CIASA should be revived and strengthened to represent the cassava value chain in SA and the full spectrum of stakeholders. It was suggested, during a workshop with R\&D stakeholders, that the constitution of CIASA should be revisited and its role should be redefined to support the cassava industry in SA as a whole, including researchers, which were not considered by the DTIC. DTIC included cassava starch in the 2016/2017 Industrial Policy action plan (IPAP) to promote trade activities in the industrialization of cassava, which was informed by the consultations leading to the establishment of CAISA.

\section{Market Creation and Product Diversification}

Although the current demand for food cassava is small in South Africa, there is the potential to develop cassava products that are affordable and attractive to consumers in South Africa. Brazil has developed a wide range of cassava food products, and benefits from a strong domestic market (Demiate and Kotovicz, 2011). High-quality cassava flour can be used as a wheat flour substitute in bread, pastries, cookies, and biscuits and as a source of food starch. Because of cassava's huge potential in the global starch market, the focus should be on the production of high-quality food starch, as well as lower value industrial products.

\section{Investment in Processing and Product Development Enterprises}

The cassava value chain starts with the production of certified planting materials, followed by primary production, and onfarm processing for the production of semi-processed products, prior to industrial processing. The development of the cassava industry can contribute to food and income security, job creation and revitalization of the rural sector. It can help address the challenges of the high starch demand and provide an avenue for import substitution. The processing industries have a key role in driving cassava development and to engage small and large starch processing enterprises in South Africa. Investment in cassava processing and product development should rely on systematic analysis of opportunities and constraints of cassava at each stage of the commodity development cycle. This can be done by stakeholders that are engaged in the development of the cassava industry that involves producers, processors and 
consumers, as well as associated national, international and nongovernmental organizations. Research and development support is essential to assist to overcome important problems within the production-processing-marketing continuum.

\section{RISK FACTORS}

\section{Frost}

Cassava being a tropical crop, it is highly sensitive to low temperatures below $18^{\circ} \mathrm{C}$ (Huang et al., 2005). Low temperature causes delayed sprouting of stem cuttings, reduced leaf expansion, low biomass accumulation and decrease storage root yield (Phoncharoen et al., 2019). In South Africa, the growing season is characterized by a hot rainy summer followed by a cold and dry winter. Frost is a major obstacle for cassava production and propagation in South Africa. There are two approaches used by researcher to cope with frost, namely the use of early bulking germplasm or pruning. All the varieties currently in the system are old cultivars that take more than 18 months to mature. Therefore, early bulking cultivars that fit into the growing season (i.e., matures within 7-9 MAP) or coldtolerant cultivars that can grow in a prolonged growth period are in demand. The Brazilian climatic condition is similar to South Africa. In the higher altitude and moisture prone areas of Brazil, farmers grow cassava in October/November and prune the cassava plant in June to avoid the cold winter. There is variation in cultivars response to pruning in terms of root yield, starch and dry matter content. Some cultivars show a reduction in root fresh yield, dry matter and starch content due to the fact that cassava plants consumed the reserve starch to overcome vegetative bud dormancy during the winter and shoot regrowth during the summer, while other continued the starch accumulation from where it stops with no reduction in yield and starch related traits (Curcelli et al., 2014). These materials are considered to be frost tolerant.

\section{Viral Disease}

Cassava production in Africa is curtailed by cassava mosaic disease (CMD) and cassava brown streak disease (CBSD) (Legg et al., 2015). CMD is a severe cassava disease prevalent in all cassava growing regions of Africa and India (Legg et al., 2011). However, variation in overall prevalence and in the severity of losses caused by the disease has been reported among regions (Ntawuruhunga et al., 2007). CMD is caused by a complex of diverse whitefly-transmitted cassava mosaic geminiviruses (CMGs) (Patil and Fauquet, 2009). The cassava geminivirus family is composed of at least 11 distinct viruses that have been characterized worldwide, of which seven have an African origin (Kuria et al., 2017). Generally, in Africa the estimated yield losses caused by CMD were reported at 15-24\%, representing 15-28 million tons of cassava production (Masinde et al., 2016). The estimated annual economic losses in East and Central Africa are estimated to be between $\$ 1.9$ and $\$ 2.7$ billion USD (Patil and Fauquet, 2009).

Cassava brown streak disease (CBSD) was restricted to the lowland coastal areas of eastern Africa (Patil et al., 2015). Recent surveys have shown that CBSD is highly prevalent in
Central, Eastern and Southern parts of Africa (Mulenga et al., 2018). It has been reported in Mozambique, Kenya, Uganda, Zambia, and Malawi (Tomlinson et al., 2018). The study by Mbewe et al. (2017) indicated the presence of two distinct virus species. CBSD does not have an obvious effect on the growth of cassava; however, the root necrosis produced by CBSD has caused a reduction in both qualitative and quantitative yield (Alicai et al., 2007) and affects maintenance of planting materials (Ndyetabula et al., 2016). Most of the yield loss from the disease is thought to be the consequence of the loss of root storability resulting from severe root rot (Hillocks et al., 2008). Gondwe et al. (2003) reported 18-25\% yield loss by CBSD, while Hillocks et al. (2001) published a yield loss estimate of $70 \%$ from the most susceptible variety. Much less attention has been given to the disease compared to $\mathrm{CMD}$, partly due to its restricted geographic distribution. However, recently the high prevalence and distribution of the disease has been reported due to presence of high population of whitefly vector B. tabaci.

\section{Market Access}

In South Africa, market access remains one of the key limiting factors for the development of emerging commercial and smallholder farmers; some institutional and technical constraints to market access in SA are well-documented (Van Schalkwyk et al., 2012). The Market for agricultural produce is largely controlled by a handful of corporate companies with excessive regulatory and compliance requirements that are beyond the means of emerging farmers. To exploit the socio-economic potential of cassava, unlocking market access and developing the entire value chain are critical. Work must start on the following key aspects to ensure the creation of sustainable market;

- Promoting the crop and ensure buy-in for primary production for food and industry,

- Understand the socioeconomic and technical production barriers,

- Organize critical mass of primary producers capable of sustainably supplying cassava raw material for starch processing industry

- Ensure farmers have access to improved varieties and production technologies that provide competitive advantage against other starch crops

- Ensure the processing industry is developed simultaneously and there exists a mutually beneficial off-take agreement and

- Introduce legislative mechanisms that favor local production and import substitution.

The ARC has already embarked in some of the aspects described above. It should be noted that there are encouraging signs that there are farmers and farmer groups ready to embark on cassava production and beneficiation. The Authors of this article have received request for production support in the form of variety choice and agronomic support in Limpopo, KwaZulu-Natal province and Mpumalanga provinces. However, ensuring market access has paramount importance before large-scale production is resumed. 


\section{CONCLUSION}

Cassava can grow and produce reasonable yields in areas where cereals and other crops are not viable. It can tolerate drought and can be grown on soils with low soil fertility, but responds well to irrigation and fertilizers. Cassava is highly flexible in its management requirements and has the potential to produce more calories per unit area of land than other crops. It is relatively resistant to major pests and diseases that affects major staple crop and be bred to tolerate the two major viral diseases with little or no yield loss. Cassava yields can be as high as $70-80 \mathrm{t} \mathrm{ha}^{-1}$ at research stations, although national yields are well below these levels and the global cassava yield is $<12 \mathrm{t} \mathrm{ha}^{-1}$. The harvesting of cassava can be delayed for months, with the result that it has been used in developing countries as a famine reserve and food security crop. Delayed harvesting allows farmers to access markets when supply is low and prices peak. Although cassava has been considered as a poor man food crop, it has the potential to develop as a major industrial crop in Africa. Cassava starch has some unique characteristics that favor its use in specialized market niches.

Exploiting the industrial potential of cassava in South Africa will improve rural livelihoods through income generation and job creation. Furthermore, the national economy should benefit indirectly from job creation, and directly from foreign exchange savings originating from replacing imported products and raw materials.

The key to exploiting the full potential of cassava largely lies in establishment of national R\&D strategy that focus on satisfying the local starch demand in the short term and export oriented starch production in the long ran.

\section{REFERENCES}

Abass, A. B., Mlingi, N., Ranaivoson, R., Zulu, M., Mukuka, I., Abele, S., et al. (2013). Potential for commercial production and marketing of cassava: Experiences from the small-scale cassava processing project in East and Southern Africa. Ibadan: International Institute of Tropical Agriculture (IITA).

Abdu-Raheem, K. A., and Worth, S. H. (2011). Household food security in South Africa: evaluating extension's paradigms relative to the current food security and development goals. SA J. Agr. Ext. 39, 91-103.

Adelekan, B. A. (2010). Investigation of ethanol productivity of cassava crop as a sustainable source of biofuel in tropical countries. Afr. J. Biotec. 9, 5643-5650.

Akinola, R., Pereira, L. M., Mabhaudhi, T., de Bruin F-M., and Rusch, L. (2020). A review of indigenous food crops in Africa and the implications for more sustainable and healthy food systems. Sustainability 12:3493. doi: $10.3390 /$ su12083493

Aliber, M., and Hart, T. (2009). Should subsistence farming be supported as a strategy to address rural food security? Agrekon 48, 434-58. doi: 10.1080/03031853.2009.9523835

Alicai, T., Omongo, C. A., Maruthi, M. N., Hillocks, R. J., Baguma, Y., Kawuki, R., et al. (2007). Re-emergence of cassava brown streak disease in Uganda. Plant Dis. 91, 24-29. doi: 10.1094/PD-91-0024

Altieri, M. A., Funes-Monzote, F. R., and Petersen, P. (2012). Agroecologically efficient agricultural systems for smallholder farmers: contributions to food sovereignty. Agron. Sust. Dev. 32, 1-13. doi: 10.1007/s13593-0110065-6

Amusan, L., and Olawuyi, S. O. (2018). The Menace of the Fall Armyworm: Food Security Challenges in Nigeria and South Africa. New Zealand International Review. Wellington.
A demand-driven approach should be implemented in research and development programmes to support the production and processing of cassava. Hence, it is critical that a long-term, multidisciplinary $R \& D$ programme should be established to support all facets of the cassava industry.

Development of strong value chains is vital in order to integrate cassava into the current production system; this however, should ensure primary producers remain as part of the value chain to incentivise production as opposed to the mere producers of raw material.

Implementing intensive out growers production system for small-scale farmers is imperative together with farmer support program.

The roles of private and public sector need to be welldefined and alignment with regional and international research community should be emphasized.

Currently, there are no improved cassava cultivar available in South Africa and the available varieties are vulnerable to diseases and have long maturity periods (>18 months) and low yields. Germplasm with high yield potential and resistance to biotic and abiotic stress factors should be imported, characterized and bred for local conditions to ensure the sustainable primary production of cassava.

\section{AUTHOR CONTRIBUTIONS}

AA designed, initiated and managed the project and contributed to manuscript preparation. MB, OM, SV, and ML contributed to manuscript preparation and edition.

Anandajayasekeram, P. (2011). "The role of agricultural R\&D within the agricultural innovation systems framework," in Proceedings of the ASTI/IFPRIFARA Conference. December 5-7, 2011. Accra.

Anikwe, M. A. N., and Ikenganyia, E. E. (2017). "Ecophysiology and production principles of cassava (Manihot species) in South Eastern Nigeria," in Cassava, ed V. Y. Waisundara (London, UK: IntechOpen), 105-122. doi: 10.5772/intechopen.70828

Aye, T. M., and Howeler, R. (2017). "Integrated crop management for cassava cultivation in Asia," in Achieving Sustainable Cultivation of Cassava. Volume 1: Cultivation Techniques. Burleigh Dodds Series in Agricultural Science, ed H. Clair (Cambridge: Burleigh Dodds Science Publishing), 424. doi: 10.19103/AS.2016.0014.23

Baker, L. (2017). "Post-apartheid electricity policy and the emergence of South Africa's renewable energy sector," in The Political Economy of Clean Energy Transitions. WIDER Studies in Development Economics, eds D. Arent, C. Arndt, M. Miller, F. Tarp, and O. Zinaman (Oxford: Oxford University Press), 371-390.

Baleta, H., and Pegram, G. (2014). Water as an Input in the Food Value Chain. Understanding the Food Energy Water Nexus. Pretoria: WWF-SA.

Benvenga, M. A. C., Librantz, A. F. H., Santana, J. C. C., and Tambourgi, E. B. (2016). Genetic algorithm applied to study of the economic viability of alcohol production from cassava root from 2002 to (2013). J. Clean Prod. 113, 483-494. doi: 10.1016/j.jclepro.2015.11.051

Bouis, H. E., and Saltzman, A. (2017). Improving nutrition through biofortification: a review of evidence from HarvestPlus, 2003 through (2016). Glob. Food Sec. 12, 49-58. doi: 10.1016/j.gfs.2017.01.009

Bunce, B. (2019). Fresh Produce Production Under Irrigation by Small-Scale Farmers in South Africa. GTAC/CBPEP/EU Project on Employment-Intensive 
Rural Land Reform in South Africa: Policies, Programmes and Capacities. Pretoria: Capacity Building Programme for Employment Promotion (CBPEP).

Burns, A. E., Gleadow, R., Anabela, Z., Cuambe, C. E., Miller, R. E., and Cavagnaro, T. (2012). Variations in the chemical composition of cassava (Manihot esculenta Crantz) leaves and roots as affected by genotypic and environmental variation. J. Agric. Food Chem. 60, 4946-56. doi: 10.1021/jf2047288

Business wire (2019). Cassava Starch Market: Global Industry Trends, Share, Size, Growth, Opportunity and Forecast 2019-2024. Available online at: https:// www.businesswire.com/news/home/20190226005819 (accessed September 20, 2020).

Cai, X., Wang, D., and Laurent, R. (2009). Impact of climate change on crop yield: a case study of rainfed corn in central Illinois. J. App. Meteor. Climat. 48, 1868-1881. doi: 10.1175/2009JAMC1880.1

Calzadilla, A., Zhu, T., Rehdanz, K., Tol, R. S. J., and Ringler, C. (2014). Climate change and agriculture: impacts and adaptation options in South Africa. Water Res. Econ. 5, 24-48. doi: 10.1016/j.wre.2014. 03.001

Carvalho, L. J. C. B., Anderson, J. V., da Silva, J. P., Chen, S., and de Souza C. R. B. (2019). Protein content in cassava storage root is associated with total abundance of carotenoids. Int. Res. J. Plant Sci. 10, 1-10. doi: 10.14303/irjps.2019.003

Ceballos, H., Davrieux, F., Talsma, E., Belalcazar, J., Chavarriaga, P., and Andersson, M. S. (2017). "Carotenoids in cassava roots," in Carotenoids eds D. Cvetkovic, and G. Nikolic (London, UK: InTechOpen), 189-221. doi: 10.5772/intechopen.68279

Chandrasekara, A., and Kumar, T. J. (2016). Roots and tuber crops as functional foods: a review on phytochemical constituents and their potential health benefits. Inter. J. Food Sci. 2016:3631647. doi: 10.1155/2016/3631647

Costa, C., and Delgado, C. (2019). The Cassava Value Chain in Mozambique. License: Creative Commons Attribution CC BY 3.0 IGO. Washington, DC: World Bank. doi: 10.1596/31754

Curcelli, F., Bicudo, S. V., Aguiar, E. B., and Valdivie, M. I. V. (2014). Pruning management of cassava for animal feeding: parameters of roots. Afr. J. Agr. Res. 9, 1238-1243. doi: 10.5897/AJAR2013.8015

Demiate, I. M., and Kotovicz, V. (2011). Cassava starch in the Brazilian food industry. Food Sci. Tech. 31, 388-397. doi: 10.1590/S0101-20612011000200017

Donnenfeld, Z., Crookes, C., and Hedden, S. (2018). A Delicate Balance: Water Scarcity in South Africa. Southern Africa Report 13. Institute for Security Studies and Frederick S. Pardee Centre for International Futures. Josef Korbel School of International Studies. Denver, CO: University of Denver, 23.

Ekop, I. E., Simonyan, K. J., and Evwierhoma, E. T. (2019). Utilization of cassava wastes for value added products: an overview. Inter. J. Sci. Engin. Sci. 3, 31-39. doi: 10.5281 /zenodo. 2556466

Elemike, E. E., Oseghale, O. C., and Okoye, A. C. (2015). Utilization of cellulosic cassava waste for bio-ethanol production. J. Env. Chem. Engin. 3, 2797-2800. doi: 10.1016/j.jece.2015.10.021

El-Sharkawy, M. A., and De Tafur, S. M. (2010). Comparative photosynthesis, growth, productivity, and nutrient use efficiency among tall- and short-stemmed rain-fed cassava cultivars. Photosynthetica 48, 173-188. doi: 10.1007/s11099-010-0023-6

FAOSTAT (2019). Food and Agriculture Organization of the United Nations statistics (FAOSTAT). FAO. Available online at: http://faostat.fao.org/default. htm (accessed August 29, 2019).

GIBS (2018). Social Enterprises in South Africa: Discovering the Vibrant Sector. Pretoria: Gordon Institute of Business Science, University of Pretoria.

Gondwe, F. M. T., Mahungu, N. M., Hillocks, R. J., Raya, M. D., Moyo, C. C., Soko, M. M., et al. (2003). "Economic losses experienced by small-scale farmers in Malawi due to cassava brown streak virus disease," in Cassava Brown Streak Virus Disease: Past, Present and Future. Proceedings of an International Workshop, Mombasa, Kenya, 27-30 October, 2002. eds J. P. Legg, and R. J. Hillocks (Aylesford: Natural Resources International Limited), 28-35.

Greyling, J. C., and Pardey, P. G. (2019). Measuring maize in South Africa: the shifting structure of production during the twentieth century, 1904-2015. Agr. Econ. Res. Pol. Prac. Southern Afr. 58, 21-41. doi: $10.1080 / 03031853.2018 .1523017$

Gwebu, J. Z., and Matthews, N. (2018). Metafrontier analysis of commercial and smallholder tomato production: a South African case. South Africa J. Sci. 114, 55-62. doi: 10.17159/sajs.2018/20170258
Hershey, C., Álvarez, E., Aye, T. M., Becerra, L. A., Bellotti, A., Ceballos, H., et al. (2012). "Eco-efficient interventions to support cassava's multiple roles in improving the lives of smallholders," in Eco-Efficiency: From Vision to Reality, eds C. Hershey, and P. Neate (Cali: Centro Internacional de Agricultura Tropical), 135-160.

Hillocks, R., Raya, M. D., Mtunda, K., and Kiozia, H. (2008). Effects of brown streak virus disease on yield and quality of cassava in Tanzania. J. Phytop. 149, 389-394. doi: 10.1111/j.1439-0434.2001.tb03868.x

Hillocks, R. J., Raya, M. D., Mtunda, K., and Kiozia, H. (2001). Effects of brown streak virus disease on yield and quality of cassava in Tanzania. J. Phytopath. 149, 389-394. doi: 10.1046/j.1439-0434.2001.00641.x

Huang, L., Ye, Z., Bell, R. W., and Dell, B. (2005). Boron nutrition and chilling tolerance of warm climate crop species. Ann. Bot. 96, 755-767. doi: $10.1093 / \mathrm{aob} / \mathrm{mci} 228$

IDC (2017). A study on Market Potential for Increased Industrial Starch Production in South Africa. Pretoria: Industrial Development Cooperation.

IPCC (2007). Climate change 2007 synthesis report. Intergovernmental Panel on Climate Change (IPCC) fourth assessment report. Available online at: http:// www.ipcc.ch/pdf/assessment-report/ar4/syr/ar4_syr.pdf (accessed August 30, 2019).

Jarvis, A., Ramirez-Villegas, J., Herrera-Campo, B. V., and Navarro-Racines, C. (2012). Is cassava the answer to African climate change adaptation? Trop. Plant Biol. 5, 9-29. doi: 10.1007/s12042-012-9096-7

Jones, R. A. C., and Barbetti, M. J. (2012). Influence of climate change on plant disease infections and epidemics caused by viruses and bacteria. CAB Rev. 7:022. doi: 10.1079/PAVSNNR20127022

Khan, M. N., Mobin, M., Abbas, Z. K., and Alamri, S. A. (2018). "Fertilizers and their contaminants in soils, surface and groundwater," in The Encyclopaedia of the Anthropocene. Volume 5, eds A. Dominick, D. Sala, and M. I. Goldstein (Oxford: Elsevier), 225-240. doi: 10.1016/B978-0-12-809665-9.09888-8

Kintché, K., Hauser, S., Mahungu, N. M., Ndonda, A., Lukombo, S. Nhamo, N., Uzokw, V. N. E., et al. (2017). Cassava yield loss in farmer fields was mainly caused by low soil fertility and suboptimal management practices in two provinces of the Democratic Republic of Congo. Europ. J. Agron. 89, 107-123. doi: 10.1016/j.eja.2017.06.011

Kuria, P., Ilyas, M., Ateka, E., Miano, D., Onguso, J., Carrington, J. C., et al. (2017). Differential response of cassava genotypes to infection by cassava mosaic geminiviruses. Virus Res. 227, 69-81. doi: 10.1016/j.virusres.2016.09.022

Legg, J. P., Jeremiah, S. C., Obiero, H. M., Maruthi, M. N., Ndyetabula, I., OkaoOkuja, G., et al. (2011). Comparing the regional epidemiology of the cassava mosaic and cassava brown streak virus pandemics in Africa. Virus Res. 159, 161-170. doi: 10.1016/j.virusres.2011.04.018

Legg, J. P., Lava-Kumar, P., Makeshkumar, T., Tripathi, L., Ferguson, M., Kanju, E., et al. (2015). Cassava virus diseases: Biology, epidemiology, and management. Adv. Virus Res. 91, 85-142. doi: 10.1016/bs.aivir.2014.10.001

Louw, A. (2013). "Sustainable policy support for smallholder agriculture in South Africa: key issues and options for consideration, "in Smallholder and Agro-food Value Chains in South Africa, ed S. Greenburg (Bellville: PLAAS), 23-28.

Lukuyu, B., Okike, I., Duncan, A., Beveridge, M., and Blümmel, M. (2014). Use of Cassava in Livestock and Aquaculture Feeding Programs. ILRI Discussion Paper 25. International Livestock Research Institute: Nairobi.

Marx, S. (2019). "Cassava as feedstock for ethanol production: a global perspective," in Bioethanol Production from Food Crops: Sustainable Sources, Interventions, and Challenges, eds R. C. Ray, and S. Ramachandran (Amsterdam: Academic Press, Elsevier), 101-110. doi: 10.1016/B978-0-12-813766-6.00006-0

Marx, S., and Nquma, T. Y. (2013). Cassava as feedstock for ethanol production in South Africa. Afr. J. Biotechnol. 12, 4975-4983. doi: 10.5897/AJB12.861

Masinde, E. A., Ogendo, J. O., Maruthi, M. N., Hillocks, R., Mulwa, R. M. S., and Arama, P. F. (2016). Occurrence and estimated losses caused by cassava viruses in Migori County, Kenya. African J. Agric. Res. 11, 2064-2074. doi: 10.5897/AJAR2016.10786

Mateo-Sagasta, J., Zadeh, S. M., and Turral, H. (2017). Water Pollution From Agriculture: A Global Review. Rome: Food and Agriculture Organization of the United Nations; Colombo: International Water Management Institute, 35.

Mbewe, W., Tairo, F., Sseruwagi, P., Ndunguru, J., Duffy, S., Mukasa, S., et al. (2017). Variability in P1 gene redefines phylogenetic relationships among cassava brown streak viruses. Virology J. 14, 1-7. doi: 10.1186/s12985-017-0790-9 
Miller, K. (2008). Climate change and water resources: the challenges ahead. J. Intern. Affa. 61, 35-50. Available online at: https://www.jstor.org/stable/ 24358110

Montagnac, J. A., Davis, C. R., and Tanumihardjo, S. A. (2009). Nutritional value of cassava for use as a staple food and recent advances for improvement. Comp. Rev. Food Sci. Food Saf. 8, 181-194. doi: 10.1111/j.1541-4337.2009.00077.x

Morgan, N. K., and Choct, M. (2016). Cassava: nutrient composition and nutritive value in poultry diets. Anim. Nut. 2, 253-261. doi: 10.1016/j.aninu.2016.08.010

Mossa, A. T. H., Mohafrash, S. M. M., and Chandrasekaran, N. (2018). Safety of natural insecticides: toxic effects on experimental animals. BioMed Res. Int. 2018:4308054. doi: 10.1155/2018/4308054

Mulenga, R. M., Boykin, L. M., Chikoti, P. C., Sichilima, S., and Ng'uni, D. (2018). Cassava brown streak disease and Ugandan cassava brown streak virus reported for the first time in Zambia. Plant Dis. 102, 1410-1418. doi: 10.1094/PDIS-11-17-1707-RE

Mupakati, T., and Tanyanyiwa, V. I. (2017). Cassava production as a climate change adaptation strategy in Chilonga Ward, Chiredzi District, Zimbabwe. J. Disas. Risk Stud. 9:348. doi: 10.4102/jamba.v9i1.348

Naab, F. Z., Dinye, R. D., and Kasanga, R. K. (2013). Urbanisation and its impact on agricultural lands in growing cities in developing countries: a case study of Tamale in Ghana. Mod. Soc. Sci. J. 2, 256-287.

Nakabonge, G., Samukoya, C., and Baguma, Y. (2018). Local varieties of cassava: conservation, cultivation and use in Uganda. Env. Dev. Sustain. 20, 2427-244. doi: 10.1007/s10668-017-9997-6

Ndyetabula, I. L., Merumba, S. M., Jeremiah, S. C., Kasela, S., Mkamilo, G. S., Kagimbo, F. M., et al. (2016). Analysis of interaction between cassava brown streak disease symptom types facilitates the determination varietal responses and yield losses. Plant Dis. 100, 1381-1396. doi: 10.1094/PDIS-11-15-1274-RE

Nguyen, T. L. T. (2007). Energy balance and GHG-abatement cost of cassava utilisation for fuel ethanol in Thailand. Ener. Pol. 35, 4585-4596. doi: 10.1016/j.enpol.2007.03.012

Ntawuruhunga, P., Okao-Okuja, G., Bembe, A., Obambi, M., Mvila, J. A. and Legg, J. (2007). Incidence and severity of cassava mosaic disease in the republic of Congo. African Crop Sci. 15, 1-9. doi: 10.4314/acsj.v15i1.54405

Nuwamanya, E., Chiwona-Karltun, L., Kawuki, R. S., and Baguma Y. (2012). Bioethanol production from non-food parts of cassava (Manihot esculenta Crantz). AMBIO 41, 262-270. doi: 10.1007/s13280-011-0183-z

Otekunrin, O. A., and Sawicka, B. (2019). Cassava, a 21st century staple crop: how can Nigeria harness its enormous trade potentials? Acta Scie. Agric. 3, 194-202. doi: 10.31080/ASAG.2019.03.0586

Pandey, R. K., Doharey, R. K., Singh, R. K., Mishra, A. K., Jeetendra, P., Manoj, K., et al. (2015). A critical analysis on training needs of farmers about mustard production technology. Inter. J. Agri. Sci. 7, 892-895. Available online at: http:// www.bioinfopublication.org/jouarchive.php?opt=\&jouid=BPJ0000217

Patil, B. L., and Fauquet, C. M. (2009). Cassava mosaic geminiviruses: actual knowledge and perspectives. Mol. Plant Pathol. 10, 685-701. doi: 10.1111/j.1364-3703.2009.00559.x

Patil, B. L., Legg, J. P., Kanju, E. E., and Fauquet, C. M. (2015). Cassava brown streak disease: a threat to food security in Africa. J. Gen. Virol. 96, 956-968. doi: 10.1099/jgv.0.000014

Perera, F. (2018). Pollution from fossil-fuel combustion is the leading environmental threat to global pediatric health and equity: solutions exist. Inter. J. Env. Res. Pub. Health 15:16. doi: 10.3390/ijerph15010016

Petrie, B. (2014). South Africa: A Case for Biomass? London: International Institute for Environment and Development, 1-39.

Phoncharoen, P., Banterng, P., Vorasoot, N., Jogloy, S., Theerakulpisut, P., and Hoogenboom, G. (2019). Growth rates and yields of cassava at different planting dates in a tropical savannah climate. Sci. Agric. 76, 376-388. doi: 10.1590/1678-992x-2017-0413

Pienaar, L., and Traub, L. (2015). "Understanding the smallholder farmer in South Africa: towards a sustainable livelihoods classification," in International Association of Agricultural Economists Conference. August 9-14, 2015. Milan.

Prochnik, S., Marri, P. R., Desany, B., Rabinowicz, P. D., Kodira, C., Mohiuddin, M., et al. (2012). The cassava genome: current progress, future directions. Trop. Plant Biol. 5, 88-94. doi: 10.1007/s12042-011-9088-z

Sanchez, T., Dominique, D., Moreno, J. L., Pizarro, M., Aragón, I. J., Dominguez M., et al. (2013). Changes in extended shelf life of cassava roots during storage in ambient conditions. Post. Biol. Technl. 86, 520-528. doi: 10.1016/j.postharvbio.2013.07.014
Sharma, H. K., Njintang, N. Y., Singhal, R. S., and Kaushal, P. (2016). Tropical Roots and Tubers: Production, Processing and Technology. Technology \& Engineering. Hoboken, NJ: John Wiley \& Sons, 648. doi: 10.1002/9781118992739

Shepherd, M., and Knox, P. (2016). The Paris COP21 climate conference: what does it mean for the southeast? Southeast Geographer. 56, 147-151. doi: $10.1353 /$ sgo.2016.0023

Singh, B. R., and Singh, O. (2012). "Study of impacts of global warming on climate change: rise in sea level and disaster frequency," in Global Warming - Impacts and Future Perspective, ed B. R. Singh (London: IntechOpen), 93-118.

STATS-SA (2017). Environmental Economic Accounts Compendium. Report No. 04-05-20. Pretoria: Statistics South Africa, 50

STATS-SA (2018). Electricity, gas and water supply industry. Report No. 41-01-02. Pretoria: Statistics South Africa, 34.

Talsma, E. F., Brouwer, I. D., Verhoef, H., Mbera, G. N. K., and Mwang, A. M. (2016). Biofortified yellow cassava and vitamin A status of Kenyan children: a randomized controlled trial. Amer. J. Clin. Nut. 103, 258-67. doi: 10.3945/ajen.114.100164

Tomlinson, K. R., Bailey, A. M., Alicai T., Seal, S., and Foster, G. D. (2018). Cassava brown streak disease: historical timeline, current knowledge and future prospects. Mol. Plant Path. 19, 1282-1294. doi: 10.1111/mpp.12613

Tonukari, N. J. (2004). Cassava and the future of starch: biotechnology issues for developing countries. Afr. J. Biotech. 7, 5-8. doi: 10.2225/vol7-issue1-fulltext-9

Trade and Development Report (2010). Agriculture at the Crossroads: Guaranteeing Food Security in a Changing Global Climate. No. 18. United Nation Conference on Trade and Development (UNCTAD) (Geneva).

UN Comtrade (2019). United Nations Commodity Trade Statistics Database. Avaialble online at: http://comtrade.un.org/ (accessed July 24, 2019).

Van Schalkwyk, H. D., Groenewald, J. A., Gavin, C. G., Fraser, G. C. G., Obi, A., and van Tilburg, A. (2012). Unlocking markets to smallholders: Lessons from South Africa. Mansholt publication series - Volume 10. Academic Publishers: Wageningen, 273. doi: 10.3920/978-90-8686-168-2

Wang, K., Yang, X., Ren, X., Zhang, J., and Mao, Z. (2017). Development of a new cleaner production process for cassava ethanol. Chinese J. Chem. Engin. 25, 493-498. doi: 10.1016/j.cjche.2016.10.002

Wang, W. (2002). "Cassava production for industrial utilization in China present and future perspective," in Cassava Research and Development in Asia: Exploring New Opportunities for an Ancient Crop. Proceedings of the Seventh Regional Cassava Workshop, Bangkok, Thailand, October 28 -November 1, 2002, ed R. H. Howlere, 33-38.

Wezel, A., Goris, M., Bruil, J., Félix, G. F., Peeters, A., Bàrberi, P., et al. (2018). Challenges and action points to amplify agro ecology in Europe. Sustainability 10:1598. doi: 10.3390/su10051598

World Bank (2008). World Development Report 2008: Agriculture for Development. License: CC BY 3.0 IGO. Washington, DC: World Bank. Avaialble online at: https://openknowledge.worldbank.org/handle/10986/5990 (accessed August 10, 2019)

Yang, X., Wang, K., Wang, H., Zhang, J., and Mao, Z. (2017). Novel process combining anaerobic-aerobic digestion and ion exchange resin for full recycling of cassava stillage in ethanol fermentation. Waste Manag. 62, 241-246. doi: 10.1016/j.wasman.2017. 01.040

Yaseen, M., Hassan, S., Tunio, M. T., Ameen, M., and Abbas, S. (2015). Role of capacity building and training for sustainable livelihood of farming community in Pakistan. Europ. Acad. Res. 3:3.

Ziervogel, G., New, M., van Garderen, E. A., Midgley, G., Taylor, A., Hamann, R., et al. (2014). Climate change impacts and adaptation in South Africa. WIREs Climate Change 5, 605-620. doi: 10.1002/wcc.295

Conflict of Interest: The authors declare that the research was conducted in the absence of any commercial or financial relationships that could be construed as a potential conflict of interest.

Copyright (๑) 2021 Amelework, Bairu, Maema, Venter and Laing. This is an openaccess article distributed under the terms of the Creative Commons Attribution License (CC BY). The use, distribution or reproduction in other forums is permitted, provided the original author(s) and the copyright owner(s) are credited and that the original publication in this journal is cited, in accordance with accepted academic practice. No use, distribution or reproduction is permitted which does not comply with these terms. 